\title{
HADIS GERHANA DAN WAFATNYA IBRAHIM IBN MUHAMMAD
}

\author{
Ahmad Ainul Yaqin dan Fahmi Fatwa Rosyadi Satria Hamdani \\ Program Pascasarjana UIN Walisongo, Fakultas Syariah Universitas Islam Bandung \\ ainayaqin2014@gmail.com, fatwa19@gmail.com
}

\begin{abstract}
ABSTRAK
Selama periode Nabi Muhammad SAW, yaitu pada kurun waktu 610-632 M, gerhana matahari telah terjadi delapan kali, yaitu empat kali terjadi pada periode Mekah dan empat kali terjadi pada periode Madinah. Kematian atau kehidupan seseorang bukanlah penyebab terjadinya gerhana, melainkan sebagai tanda kebesaran dan keagungan Tuhan Yang Maha Esa. Gerhana terbagi menjadi dua yaitu gerhana matahari atau disebut dengan kusuf asy-syams, dan gerhana bulan atau disebut dengan khusuf alqamr. Ketika terjadi fenomena gerhana, baik gerhana matahari maupun gerhana bulan maka seorang muslim dianjurkan untuk melaksanakan ibadah shalat gerhana. Gerhana matahari pernah terjadi pada zaman Nabi SAW yaitu ketika meninggalnya putera beliau Ibrahim Ibn Muhammad. Para ahli hadis dan ahli astronom berbeda pendapat terkait waktu meninggalnya Ibrahim Ibn Muhammad, namun berdasarkan riwayat-riwayat hadis dan data astronomi diketahui bahwa Ibrahim Ibn Muhammad meninggal pada hari senin 27 Januari $632 \mathrm{M}$ atau 29 Syawal $10 \mathrm{H}$ dengan usia 1 tahun 10 bulan (22 bulan).
\end{abstract}

\section{Kata Kunci: Gerhana, Hadis, Kematian Ibrahim Ibn Muhammad}

\begin{abstract}
During the time of Prophet Muhammad SAW, in the period 610-632 AD, the solar eclipse has occurred eight times. Four times occurred in the Makkah period and four times in the Medina period. Death or life of a person is not the cause of the occurrence of eclipses, but as a sign of greatness and majesty of Allah SWT. The eclipse is divided into two, a solar eclipse or called kusuf ash-shams, and a lunar eclipse or called khusuf al-qamr. When the eclipse phenomenon occurs, both a solar eclipse and a lunar eclipse then a Muslim is recommended to implement the eclipse prayer. The solar eclipse occurred at the time of Prophet SAW when the death of his son Ibrahim bin Muhammad. The scholars of Hadith and astronomers differed in the time of the death of Ibrahim Ibn Muhammad, but based on the hadith and astronomical data it is known that Ibrahim Ibn Muhammad died on Monday 27 January 632 AD or 29 Syawal $10 \mathrm{H}$ with the age of 1 year 10 months (22 months).
\end{abstract}

Keywords: Eclipse, Hadith, Death of Ibrahim Ibn Muhammad 


\section{A. PENDAhuluaN}

Gerhana, dalam bahasa Inggris dikenal dengan istilah 'eclipse' dan dalam bahasa Arab dikenal dengan 'kusuf' atau 'khusuf'. Pada dasarnya istilah kusuf dan khusuf dapat dipergunakan untuk menyebut gerhana matahari maupun maupun bulan. Hanya saja, kata kusuf lebih dikenal untuk menyebut gerhana matahari, sedangkan khusuf untuk menyebut gerhana bulan. ${ }^{1}$

Fenomena gerhana sering kali oleh masyarakat awam dikaitkan dengan suatu peristiwa tertentu yang terjadi di sekelilingnya, padahal itu semua hanyalah mitos dan gerhana sendiri merupakan salah satu bukti keagungan Sang Pencipta. ${ }^{2}$ Di zaman Nabi SAW pernah terjadi gerhana matahari dan peristiwa itu dilaporkan dalam banyak riwayat hadis yang di takhrij oleh para ahli hadis. Hanya saja riwayat-riwayat hadis itu tidak mencatat tanggal dan hari terjadinya gerhana itu. Riwayat-riwayat tersebut tampaknya lebih terfokus pada aspek tuntunan ibadah saat terjadi gerhana, yaitu Salat gerhana.

Pada sisi lain putra Nabi SAW yaitu Ibrahim di dalam beberapa riwayat disebutkan meninggal dunia saat masih kecil yaitu pada hari terjadinya gerhana matahari tersebut. Beberapa riwayat menyepakati bahwa Ibarahim lahir tahun $8 \mathrm{H}$, namun riwayat tersebut tidak menyepakati kapan meninggalnya dan berapa usianya saat meninggal. Ada yang mengatakan usianya ketika meninggal yaitu 16 bulan, 18 bulan dan 22 bulan. ${ }^{3}$ Oleh karena itu, dalam kesempatan ini penulis akan mencoba mengungkap tentang awal di syariatkannya Salat gerhana dan mengetahui secara rinci kapan gerhana matahari terjadi pada zaman Nabi SAW, yang bertepatan dengan meninggalnya putera Nabi yaitu Ibrahim Ibn Muhammad.

\section{B. METODE PENELITIAN}

Penelitian ini menggunakan pendekatan kualitatif dengan metode analisis konsep. Adapun teknik pengumpulan data dilakukan dengan cara mengumpulkan beberapa literatur hadis yang berkaitan dengan gerhana, selanjutnya dilakukan analisa terhadap

\footnotetext{
${ }^{1}$ Muhyiddin Khazin, Ilmu Falak dalam Teori dan praktik, (Yogyakarta: Buana Pustaka, cet. 3, 2004), hlm. 187.

${ }^{2}$ Fahmi Fatwa Rosyadi Satria Hamdani, "Penerapan Model Contextual Teaching and Learning (CTL) dalam Pembelajaran Ilmu Falak,” Jurnal al-Murabbi, Volume. 3 (1), 2016, hlm.56.

${ }^{3}$ Syamsul Anwar, Interkoneksi Studi Hadis dan Astronomi, (Yogyakarta: Suara Muhammadiyah, 2011), hlm. 157.
} 
hadis-hadis tersebut dan literatur bacaan lainnya terkait wafatnya Ibrahim bin Muhammad.

\section{PEMBAHASAN}

\section{Perintah Salat Gerhana}

Dalam shahih bukhari dijelaskan:

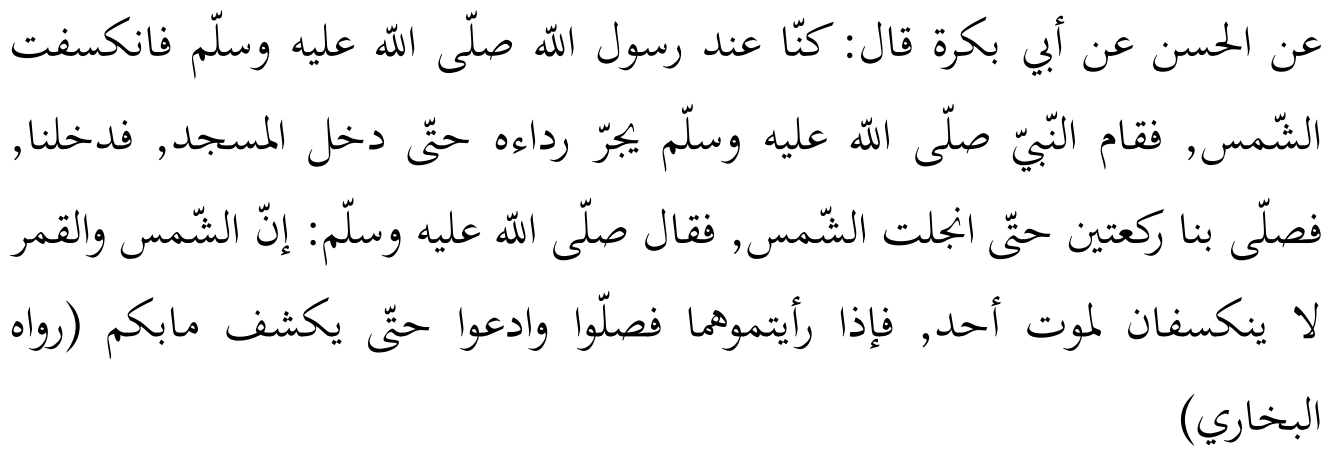

Dari Hasan, dari Abu Bakrah, dia berkata, kami berada di sisi Rasulullah SAW dan matahari mengalami kusuf (gerhana), maka Nabi SAW berdiri dengan menyeret selendangnya hingga masuk masjid. Maka, kami pun (ikut) masuk ke dalamnya. Lalu Nabi SAW Salat dua rakaat mengimami kami hingga matahari tampak (kembali). Lalu Nabi SAW bersabda, "Sesungguhnya matahari dan bulan tidak mengalami kusuf (gerhana) karena kematian seseorang. Apabila kalian melihat keduanya (mengalami gerhana), maka Salat dan berdoalah hingga disingkapkan apa yang ada pada kalian". (HR. Bukhari) ${ }^{4}$

Disyariatkannya salat saat terjadi kusuf (gerhana) ini merupakan hal yang disepakati, namun yang diperselisihkan adalah tentang hukum dan caranya. Mayoritas ulama mengatakan hukumnya adalah sunnah mu'akkadah (yang sangat dianjurkan). Akan tetapi Abu Awanah dalam kitab shahihnya dan Ibnu Al-Manayyar menukil dari Abu Hanifah menyatakan bahwa hukumnya adalah wajib. Sementara itu Imam Malik menyamakan Salat gerhana dengan Salat Jumat. ${ }^{5}$

Adapun mengenai cara Salat gerhana para ulama berbeda pendapat. Muslim meriwayatkan dari Aisyah, dari Ibnu Abbas dari Jabir, bahwa Salat gerhana dilakukan dua rakaat, dan pada setiap rakaat ada tiga kali rukuk. Dari Ibnu Abbas dan Ali, Salatnya dua rakaat, dan pada setiap rakaat ada empat kali rukuk. Sementara dalam riwayat milik

\footnotetext{
${ }^{4}$ Ibnu Hajar Al-Asqalani, Fathul Baari syarah: Shahih Bukhari, terj. Gazirah Abdi Ummah (Jakarta: Pustaka Azzam, 2008, cet. 2, vol. VI), hlm. 2.

${ }^{5}$ Ibnu Hajar Al-Asqalani, Fathul Baari......., hlm.4.
} 
Abu Dawud, dari Ubay bin Ka'ab, Salat gerhana terdiri dari dua rakaat, dan pada setiap rakaat ada lima kali rukuk. Pendapat yang populer adalah dari jumhur ulama yaitu Salat gerhana dilakukan dua rakaat, pada setiap rakaat dua kali berdiri, dua kali membaca ayat, dan dua kali rukuk. Adapun sujud hanya dua kali seperti Salat lainnya, baik gerhana tersebut terjadi terus menerus maupun tidak. Pendapat ini dikemukakan oleh madzhab Imam Syafi'I, Malik, Al-Laits, Ahmad, Abu Tsaur, mayoritas ulama Hijaz (daerah sekitar Mekah, Madinah, dan Jedah). ${ }^{6}$

فقام النّبّ صلّى الله عليه وسلّم يجرّ رداءه selendangnya). Dalam pembahasan tentang al-libas (pakaian) tersebut diriwayatkan dari Yunus disebutkan istilah مستعجلا (dengan tergesa-gesa). Dalam riwayat an-Nasa'i dari Yazid bin Zurai', dari Yunus disebutkan من العجلة (dengan tergesa-gesa). Sedangkan كسفت الثمّمس على عهد رسول الله dalam riwayat Imam Muslim dari hadis Asma’ disebutkan (terjadi gerhana matahari pada masa Rasulullah SAW, maka beliau merasa cemas dan terburu-buru hingga salah memakai baju besi sampai ia mendapatkan selendangnya). Yakni beliau hendak memakai baju besi karena hatinya cemas dan takut. Hal ini dijadikan dalil bahwa menyeret pakaian tidak tercela, kecuali bagi orang yang bertujuan untuk menyombongkan diri.

فصلّى بنا ركتنين (maka Nabi SAW Salat dua rakaat mengimami kami). An-Nasa'i menambahkan كما تصلّون (sebagaimana kalian Salat). Hal ini dijadikan dalil bahwa Salat gerhana sama seperti Salat sunah (nafilah). Lafadz حنّى انجلت (hingga matahari tampak), ini dijadikan dalil tentang lama Salat gerhana, yaitu hingga matahari nampak kembali. Namun Ath-Thahawi menjawab, bahwa dalam hadis dikatakan فصلّو او ادعوا (hendaklah kalian Salat dan berdoa). Dalam arti lain, jika kita selesai melaksankan Salat gerhana, namun matahari belum juga nampak (muncul kembali), maka hendaknya kita menyibukkan diri dengan berdoa hingga gerhana berakhir. ${ }^{7}$

Sementara dalam shahih Muslim menyebutkan:

${ }^{6}$ Imam An-Nawawi, Syarah Shahih Muslim, terj. Team Darus Sunnah, (Jakarta: Darus Sunnah, cet. 3, vol. 4, 2014), hlm. 790.

${ }^{7}$ Ibnu Hajar Al-Asqalani, Fathul Baari........, hlm. 4-6. 


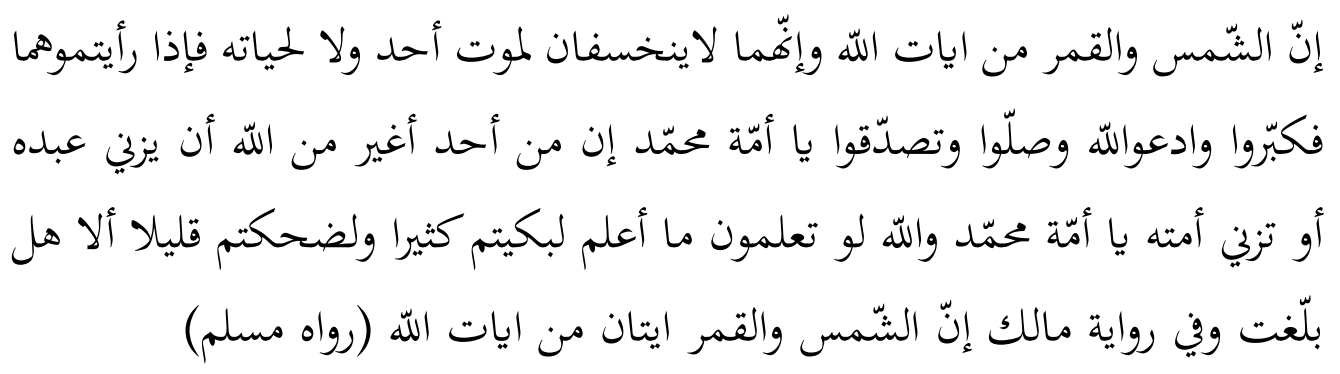

"Sesungguhnya matahari dan bulan adalah termasuk dari tanda-tanda kebesaran Allah, gerhana terjadi pada keduanya bukan karena kematian seseorang dan tidak juga karena kehidupan seseorang. Maka jika kalian melihatnya, hendaklah hendaklah bertakbir, berdoa kepada Allah, melakukan Salat, dan bersedekah. Wahai umat Muhammad, tidak ada seorangpun yang lebih cemburu daripada Allah apabila hambanya yang laki-laki atau hambanya yang perempuan melakukan perzinahan. Wahai umat Muhammad, demi Allah, jika kalian mengetahui apa yang aku ketahui niscaya kalian akan banyak menangis dan sedikit tertawa. Ketahuilah apakah aku sudah menyampaikannya?" Di dalam riwayat Malik, "Sesungguhnya matahari dan bulan adalah dua tanda dari tandatanda kebesaran Allah". (HR. Muslim) ${ }^{8}$

Hadis yang diriwayatkan Muslim tersebut diatas memerintahkan kepada umat muslim untuk melaksanakan Salat, berdoa dan bersedekah ketika melihat gerhana. Hadis ini senada dengan hadis yang diriwayatkan oleh Abu Dawud sebagai berikut:

$$
\text { ولا لحن عائشة: أنّ النّيّ صلّى اللّ عليه وسلّم قال: الشّمس والقمر لا يخسفان لموت احد }
$$

Dari Aisyah R.A. bahwa Nabi SAW bersabda: "Matahari dan bulan tidak gerhana karena matinya seseorang dan tidak pula karena kehidupannya. Apabila kamu mengetahuinya, maka berdoalah kepada Allah Azza Wajalla, bertakbirlah dan bersedekahlah.9

Imam Ad-Darimi, Sunan Ad-Darimi menjelaskan:

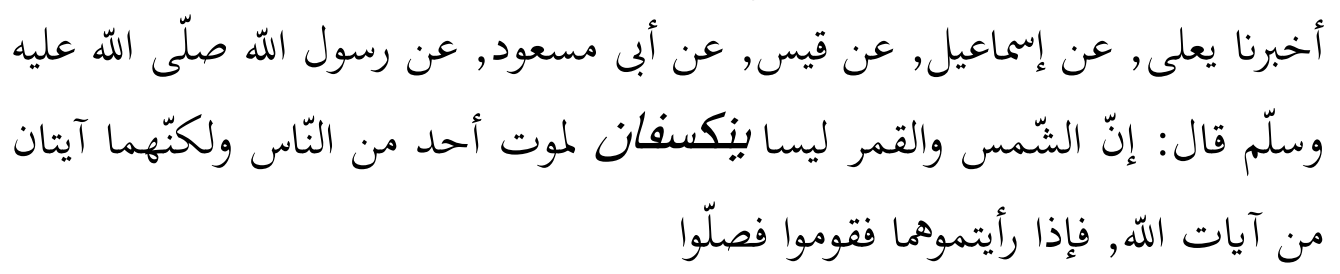

Ya'la menceritakan kepada kami, dari Ismail, dari Qais, dari Abu Mas'ud, dari Rasulullah SAW, beliau bersabda, "Sesungguhnya terjadinya gerhana matahari dan bulan bukan disebabkan oleh meninggalnya seseorang. Namun, keduanya

\footnotetext{
${ }^{8}$ Imam An-Nawawi, Syarah Shahih Muslim, .........., hlm. 780-781.

9 Hafidz Al-Mundziry, Mukhtashar Sunan Abi Dawud, terj. Bey Arifin dan A. Syinqithy Djamaluddin, (Semarang: Asy-Syifa', 1992), hlm. 106.
} 
merupakan salah satu tanda kebesaran dan kekuasaan Allah SWT. Jika kalian menyaksikan gerhana, maka lakukanlah Salat."10

\section{Istilah Kusuf dan Khusuf}

$$
\begin{aligned}
& \text { عن عروة بن الزّبير أنّ عائشة زوج النّبيّ صلّى اللّ عليه وسلّم أخبرته أنّ رسول الله صلّى } \\
& \text { الله عليه وسلّم صلّى يوم خسفت الشّمس فقام فكبّ فقرأ قراءة طويلة ثمّ ركع ركوعا } \\
& \text { طويلا ثمّ رفع رأسه فقال: سمع الله لمن حمده. وقام كما هو ثمّ قرأ قراءة طويلة وهي } \\
& \text { أدنى من القراءة الأولى ثمّ ركع ركوعا طويلا وهي أدنى من الرّكعة الأولى ثُّ سجد سجودا } \\
& \text { طويالا ثمّ فعل في الرَكعة الأخرة مثل ذلك ثمّ سلّم وقد بحلّت الثّمس فخطب النّاس } \\
& \text { فقال في كسوف الشّمس والقمر: إذّما ايتان من ايات الله لايخسفان لموت أحد ولا } \\
& \text { لحياته, فإذا رأيتموهما فافزعوا إلى الصّاة (رواه البخاري) }
\end{aligned}
$$

Dari Urwah bin Zubair bahwa Aisyah (istri Nabi SAW) mengabarkan kepadanya, "Sesungguhnya Rasulullah SAW pada saat khusuf (gerhana) matahari, beliau berdiri dan takbir lalu membaca bacaan yang panjang. Kemudian beliau melakukan ruku' yang lama, lalu mengangkat kepalanya dan mengucapkan 'sami'allahu liman hamidah'. Kemudian beliau berdiri sebagaimana semula, lalu membaca bacaan yang panjang namun lebih pendek daripada bacaan pertama. Kemudian beliau melakukan ruku' yang lama namun lebih singkat daripada ruku' pertama. Setelah itu beliau melakukan sujud yang lama. Lalu beliau melakukan hal yang sama seperti itu pada rakaat terakhir. Kemudian beliau mengucapkan salam dan matahari telah nampak dan berkhutbah kepada manusia, dimana beliau bersabda tentang kusuf (gerhana) matahari dan bulan, 'sesungguhnya keduanya adalah dua tanda diantara tandatanda (kebesaran) Allah, keduanya tidak mengalami gerhana karena kematian seseorang dan tidak pula karena kehidupannya (kelahirannya). Apabila kalian melihat keduanya, maka bersegeralah kepada Salat'.” (HR. Bukhari)

Dalam bahasa Arab dikatakan كسوف الثّمس و القمر (terjadi gerhana matahari dan bulan). Kata كسَف _ كسبف - انكسف dan memiliki satu makna yang sama خسف القمر artinya gerhana matahari, sedangkan gسف الثّمس yaitu gerhana. Dikatakan artinya gerhana bulan. ${ }^{11}$ Al-Qadhi Iyadh meriwayatkan dari sebagian pakar bahasa Arab

${ }^{10}$ Imam Ad-Darimi, Sunan Ad-Darimi, terj. Abdul Syukur Abdul Razaq (Jakarta: Pustaka Azzam, jilid I, 2007), hlm. 865 .

${ }^{11}$ Imam An-Nawawi, Syarah Shahih Muslim, hlm. 789. 
dan ulama terdahulu, mengatakan dengan sebaliknya yaitu kusuf untuk gerhana bulan sedangkan khusuf untuk gerhana matahari. Namun pendapat ini salah dan bertentangan dengan firman Allah SWT dalam QS. Al-Qiyaamah ayat 8, yaitu:

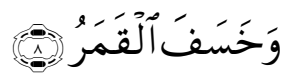

"Dan apabila bulan telah hilang cahayaNya" (QS. Al-Qiyaamah: 8).

Penyebutan وخسف القمر dalam QS. Al-Qiyaamah ayat 8 diatas mengandung dua kemungkinan. Pertama, lafadz khusuf hanya digunakan untuk gerhana bulan seperti yang tercantum dalam al-Qur'an. Sehingga, jika lafadz khusuf hanya digunakan untuk gerhana bulan, maka berarti lafadz kusuf khusus digunakan untuk gerhana matahari. Kedua, apa yang berlaku bagi matahari berlaku pula pada bulan. Sehingga, jika dalam al-Qur'an gerhana bulan diungkapkan dengan lafadz khusuf, maka lafadz khusuf juga bisa digunakan untuk gerhana matahari.

Pendapat yang masyhur menurut ahli fiqih (fuqaha) menjelaskan bahwa lafadz kusuf adalah untuk gerhana matahari, sedangkan lafadz khusuf adalah untuk gerhana bulan, sebagaimana pendapat Tsa'lab. Al-Jauhari menyebutkan bahwa yang demikian lebih fasih (baku), bahkan sebagian mengharuskan demikian. Namun ada pendapat lain yang mengatakan bahwa kusuf adalah untuk permulaan gerhana, sedangkan khusuf adalah untuk akhir gerhana. Ada pula yang mengatakan bahwa kusuf digunakan apabila cahaya itu hilang sama sekali (gerhana total), sedangkan khusuf digunakan untuk sebagian cahaya (gerhana sebagian). Sebagian lagi mengatakan bahwa khusuf digunakan untuk apabila seluruh warna hilang (tidak tampak), sedangkan kusuf adalah untuk terjadinya perubahan. $^{12}$

\section{Gerhana pada Hari Kematian Ibrahim Ibn Muhammad Saw}

$$
\begin{aligned}
& \text { عن المغيرة بن شعبة قال: كسفت الشّمس على عهد رسول اللّ صلّى الله عليه وسلّم } \\
& \text { يوم مات ابراهيم, فقال النّاس: كسفت الثّمس لموت ابراهيم. فقال رسول الله صلّى }
\end{aligned}
$$

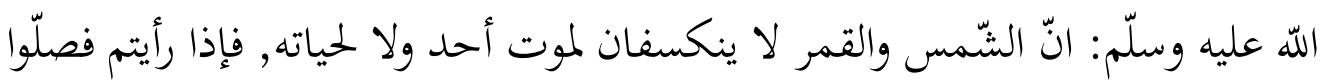

$$
\begin{aligned}
& \text { وادعوا الله (رواه البخاري واللفظ له ورواه مسلم وابو داود) }
\end{aligned}
$$

\footnotetext{
${ }^{12}$ Ibnu Hajar Al-Asqalani, Fathul Baari........, hlm. 32-33.
} 
"Dari Al Mughiroh bin Syu'bah, dia berkata, matahari mengalami kusuf (gerhana) pada masa Rasulullah SAW di hari meninggalnya Ibrahim (putra Rasulullah). Maka manusia berkata, "Matahari mengalami kusuf (gerhana) karena kematian Ibrahim". Lalu Rasulullah SAW bersabda, "Sesungguhnya matahari dan bulan tidak mengalami kusuf (gerhana) karena kematian seseorang dan tidak pula karena kehidupannya (kelahirannya). Apabila kalian melihat (gerhana), maka hendaklah kalian Salat dan berdo'a kepada Allah" (HR. Al-Bukhari dan ini adalah lafalnya, juga riwayat Muslim dan Abu Dawud). ${ }^{13}$

Hadis diatas menjelaskan bahwa gerhana di masa Rasulullah SAW itu terjadi pada hari wafatnya putera Nabi SAW yaitu Ibrahim dari Maria al-Qibtiyyah. Maria dan saudara perempuannya yang bernama Sirin adalah dua orang budak perempuan yang dihadiahkan oleh Mukaukis (Gubernur Romawi di Iskandariah) kepada Rasulullah SAW. Maria dinikahi oleh Rasulullah SAW secara milkul-yamin, dan Sirin diberikannya kepada Penyair Hassan Ibn Tsabit dan melahirkan 'Abd ar-Rahman Ibn Hassan. Sedangkan Maria melahirkan Ibrahim Ibn Muhammad SAW dan kemudian ia dibebaskan oleh Rasulullah SAW dari perbudakan. (Kecuali Ibrahim), seluruh putera dan puteri Nabi SAW adalah dari Khadijah binti Khuwailid yang merupakan isteri pertama Rasulullah SAW yang telah meninggal dunia pada 3 tahun sebelum Hijrah Nabi. ${ }^{14}$

Ketika orang-orang mengatakan كسفت الثُمس لموت ابراهيم (matahari mengalami kusuf (gerhana) karena kematian Ibrahim), kemudian Nabi SAW membantah perkataan mereka yaitu انّ الثّمس و القمر لا ينكسفان لموت أحدو لا لحياته (Sesungguhnya matahari dan bulan tidak mengalami kusuf (gerhana) karena kematian seseorang dan tidak pula karena kelahirannya). Para ulama berpendapat, hikmah dari perkataan ini adalah sebagian orangorang jahiliyah mengagungkan matahari dan bulan, padahal keduanya adalah dua makhluk Allah SWT dan juga tanda-tanda kebesaran-Nya, yang keduanya tidak mempunyai keistimewaan. Keduanya sama seperti makhluk-makhluk lain yang mempunyai kekurangan dan perubahan bentuk. Sebagian orang-orang sesat dari ahli Nujum mengatakan "Gerhana tidak terjadi, melainkan karena kematian orang besar atau yang lainnya." Kemudian Nabi SAW menjelaskan bahwa perkataan tersebut adalah

\footnotetext{
${ }^{13}$ Ibid. hlm. 3-4.

${ }^{14}$ Syamsul Anwar, Interkoneksi, .......... Hlm.164.
} 
salah, tidak boleh terpengaruh oleh perkataan mereka, terlebih lagi secara kebetulan gerhana terjadi bertetapan dengan kematian Ibrahim. ${ }^{15}$

Menurut Ibnu Hajar Al-Asqalani dalam Fathul Baari menjelaskan tentang يو مات (pada hari meninggalnya Ibrahim), yakni Ibrahim bin Muhammad SAW. Mayoritas sejarahwan mengatakan bahwa Ibrahim meninggal pada tahun ke-10 H. Ada yang mengatakan pada bulan Rabi'ul Awwal, ada yang mengatakan juga pada bulan Ramadhan, sementara sebagian yang lain mengatakan pada bulan Dzulhijjah. Mayoritas mereka mengatakan bahwa kejadian ini berlangsung pada hari kesepuluh. Sebagian mengatakan pada hari keempat, dan sebagian lagi mengatakan pada hari keempat belas. Namun penetapan hari ini tidak dapat dibenarkan jika dikatakan bahwa peristiwa itu berlangsung pada bulan Dzulhijjah, sebab Nabi SAW saat itu berada di Makkah untuk menunaikan ibadah haji. Sementara telah dinukil melalui riwayat yang akurat bahwa beliau SAW menyaksikan kematian anaknya (Ibrahim) ketika berada di Madinah.

Imam An-Nawawi menegaskan bahwa Ibrahim meninggal dunia pada tahun perjanjian Hudaibiyah. Namun pernyataan An-Nawawi ditanggapi oleh ahli astronomi, bahwa beliau Nabi SAW saat itu berada di Hudaibiyah dan kembali ke Madinah pada akhir bulan. Sementara Imam Syafi'i berpandangan bahwa gerhana itu terjadi pada hari raya. Namun pernyataan Imam Syafi'i tersebut juga ditolak oleh mereka yang berpegang dengan pandangan para ahli astronomi. Dari keterangan-keterangan diatas terdapat bantahan bagi ahlul hai'ah (para ahli astronomi) yang beranggapan bahwa kematian yang dimaksud tidak mungkin terjadi pada waktu-waktu yang telah disebutkan oleh fuqaha dan ahli riwayat (yaitu tanggal 10, 4 , atau 14). ${ }^{16}$

Semua riwayat menyepakati bahwa Ibrahim lahir di bulan Dzulhijjah tahun $8 \mathrm{H}$ (Maret $630 \mathrm{M}$ ) tanpa menyebutkan tanggal pastinya. Akan tetapi riwayat-riwayat itu tidak sepakat tentang usia Ibrahim ketika meninggal dan tentang tahun meninggalnya. Ada yang menyatakan bahwa usianya ketika wafat adalah 70 atau 71 malam. Beberapa sumber menyebutkan bahwa Ibrahim meninggal dalam usia 18 bulan dan ada juga yang mengatakan 22 bulan (1 tahun 10 bulan). Namun mayoritas ahli riwayat menyatakan

\footnotetext{
${ }^{15}$ Imam An-Nawawi, Syarah Shahih Muslim, .........., hlm.793.

${ }^{16}$ Ibnu Hajar Al-Asqalani, Fathul Baari........, hlm. 11.
} 
bahwa usianya saat meninggal adalah 16 bulan, hal ini dijelaskan dalam hadits yang diriwayatkan oleh 'Abd- ar-Razzaq berikut:

$$
\begin{aligned}
& \text { عن البرّاء بن عازب قال توفيّ إبراهيم بن النّبّ صلّى اللّ عليه وسلّم وهوابن ستّة عشر } \\
& \text { شهرا فقال النّيّ صلّى اللّ عليه وسلّم ادفنوه بالبقيع فإنّ له مرضعا تتمّ رضاعه في } \\
& \text { الجنّة (رواه عبد الرزاق) }
\end{aligned}
$$

'Dari al-Barra' Ibn 'Azib (diriwayatkan bahwa) ia berkata: Ibrahim putera Nabi SAW meninggal ketika berusia 16 bulan, maka Nabi SAW bersabda: Makamkanlah ia di al-Baqi'; ia akan mendapatkan ibu susu yang akan menyempurnakan susuannya di surga" (HR. 'Abd ar-Razzaq). ${ }^{17}$

Apabila Ibrahim lahir bulan Dzulhijjah tahun $8 \mathrm{H}$, maka bila ia berusia 71 hari berarti ia meninggal pada akhir bulan Muharram tahun $9 \mathrm{H}$; apabila berusia 16 bulan berarti meninggal akhir Rabiul Akhir tahun $10 \mathrm{H}$; apabila berusia 18 bulan berarti meninggal bulan Jumadil Akhir; apabila berusia 1 tahun 10 bulan berarti meninggal pada bulan Syawal 10 H. Riwayat-riwayat hadis menyepakati bahwa Ibrahim meninggal pada tahun $10 \mathrm{H}$, namun mengenai hari dan tanggalnya tidak ada kesepakatan. Akan tetapi ada hadis yang secara jelas menyatakan bahwa Ibrahim meninggal pada hari selasa 10 Rabiul Awal tahun $10 \mathrm{H}$, yaitu:

$$
\begin{aligned}
& \text { عن سيرين قالت حضرت موت إبراهيم بن رسول الله صلّى اللّ عليه وسلّم وكنت كلّما صحت } \\
& \text { و أختي وصاح النّساء لاينهانا فلمّا مات فهانا عن الصيّاح وحمله المى شفير القبر والعبّاس إلى جنبه } \\
& \text { ونزل في قبره الفضل بن عبّاس وأسامة بن زيد وأنا أبكي عند قبره وكسفت الشّمس } \\
& \text { فقال النّاس هذا لموته فقال رسول اللّ صلّى الله عليه وسلّم إفّّا لا تكسف لموت أحد } \\
& \text { ولا لحياته ورأى رسول الله صلّى الله عليه وسلّم فرجة في القبر فأمر بها أن تسدّ فقيل } \\
& \text { يا رسول الله هل تنفعه فقال أما إذّا لا تنفعه ولا تضرّه ولكن تضرّ بعين الحيّ ومات } \\
& \text { يوم الثّلاثاء لعشر خلون من ربيع الأوّل سنة عشر (رواه الطبّرانى) }
\end{aligned}
$$

Dari Sirin (diriwayatkan bahwa) ia berkata: saya melayat kematian Ibrahim Ibn Rasulullah SAW. Sebelumnya ketika saya, saudara perempuan saya (sirin), dan para wanita menangis meraung-raung Rasulullah SAW tidak melarangnya.

17 Dikutip Syamsul Anwar, Interkoneksi Studi Hadis dan Astronomi, (Yogyakarta: Suara Muhammadiyah, 2011), h. 160. Dari 'Abd ar-Razzaq, al-Mushannaf, edisi Habib ar-Rahman (Beirut: alMaktab al-Islami, 1403), 7 : hlm. 494. 


\begin{abstract}
Akan tetapi ketika Ibrahim meninggal Rasulullah SAW melarang menangis meraung-raung. Beliau membawa (jasad) Ibrahim ke tepi kuburnya di dampingi oleh al-Abbas, dan yang masuk ke kuburnya adalah al-Fadl Ibn al-Abbas dan Usamah Ibn Zaid, sementara saya menangis di pinggir kubur. Matahari gerhana sehingga orang-orang berkata: gerhana ini karena kematiannya. Maka Rasulullah SAW bersabda: matahari gerhana bukan karena mati dan hidupnya seseorang. Kemudian Rasulullah SAW melihat ada lobang di8 dalam kubur kubur itu dan beliau menyuruh menutupnya. Ada yang bertanya: Apa itu bermanfaat baginya wahai Rasulullah?Beliau menjawab: Itu memang tidak berguna dan tidak merusaknya, hanya merusak dalam pandangan mata orang yang masih hidup. Ibrahim meninggal pada sepuluh hari telah berlalu bulan Rabiul Awal tahun sepuluh (HR. At-Tabarani). ${ }^{18}$
\end{abstract}

\title{
4. Interkoneksi Hadis dan Astronomi tentang Wafatnya Ibrahim Ibn
}

\section{Muhammad Saw}

Berdasarkan perhitungan dengan Solar Eclipse Explorer (NASA), ${ }^{19}$ diketahui bahwa pada periode Nabi SAW di Mekah dan Madinah telah terjadi delapan kali gerhana matahari, yang terdiri dari empat kali gerhana matahari selama periode Mekah dan empat kali gerhana matahari periode Madinah. Untuk lebih jelasnya berikut adalah data gerhana matahari pada periode Rasulullah SAW: ${ }^{20}$

1. Data gerhana matahari periode Mekah (610-622 M)

Tahun 613 : 23 Juli $613 \mathrm{M} / 29$ Ramadhan $10 \mathrm{SH}$

Tahun 616 : 21 Mei $616 \mathrm{M} / 29$ Syakban $7 \mathrm{SH}$

Tahun 617 : 4 November $617 \mathrm{M} / 29$ Syafar $5 \mathrm{SH}$

Tahun 620 : 2 September $620 \mathrm{M} / 29$ Muharam $2 \mathrm{SH}$

18 Dikutip Syamsul Anwar, Interkoneksi Studi Hadis dan Astronomi, (Yogyakarta: Suara Muhammadiyah, 2011), h. 161. Dari At-Tabarani, al-Mu'jam al-Kabir, edisi Hamdi Ibn 'Abd al-Majid asSilafi, cet. Ke-2 (Mosul, Suriah: Maktabat az-Zahra, 1404/1983), XXIV: 306. WIB.

${ }^{19}$ https://eclipse.gsfc.nasa.gov/JSEX/JSEX-AS.html, diakses pada 8 Desember 2017 pukul 04.50

${ }^{20}$ Syamsul Anwar, Interkoneksi, hlm. 170 
Latitude: $21^{\circ} 25^{\prime} 21^{\prime \prime} \mathrm{N}$ Longitude: $39^{\circ} 49^{\prime} 34^{\prime \prime} \mathrm{E}$

Altitude: $304 \mathrm{~m}$

Time Zone: 03:00 E

\begin{tabular}{|c|c|c|c|c|c|c|c|c|c|c|c|c|c|}
\hline $\begin{array}{l}\text { Calendar } \\
\text { Date }\end{array}$ & \begin{tabular}{|l|} 
Eclipse \\
Type
\end{tabular} & \begin{tabular}{|l|} 
Partial \\
Eclipse \\
Begins
\end{tabular} & \begin{tabular}{|l|} 
Sun \\
Alt
\end{tabular} & \begin{tabular}{|l} 
A or $\mathrm{T}$ \\
Eclipse \\
Begins
\end{tabular} & \begin{tabular}{|l|} 
Maximum \\
Eclipse
\end{tabular} & $\begin{array}{l}\text { Sun } \\
\text { Alt }\end{array}$ & $\begin{array}{l}\text { Sun } \\
\text { Azi }\end{array}$ & $\begin{array}{l}\text { A or T } \\
\text { Eclipse } \\
\text { Ends }\end{array}$ & \begin{tabular}{|l|} 
Partial \\
Eclipse \\
Ends
\end{tabular} & $\begin{array}{l}\text { Sun } \\
\text { Alt }\end{array}$ & $\begin{array}{l}\text { Eclipse } \\
\text { Mag. }\end{array}$ & $\begin{array}{l}\text { Eclipse } \\
\text { Obs. }\end{array}$ & \begin{tabular}{|l} 
A or $\mathbf{T}$ \\
Eclipse \\
Duration
\end{tabular} \\
\hline 601-Mar-10 & $\mathrm{P}$ & 09:32:36 & 40 & - & 10:54:03 & 56 & 133 & - & 12:22:22 & 65 & 0.744 & 0.684 & - \\
\hline 603-Aug-12 & $\mathrm{P}$ & 18:36:43 & 02 & - & $18: 48(\mathrm{~s})$ & $0(s)$ & 286 & - & 18:48(s) & $0(s)$ & $0.228(\mathrm{~s})$ & $0.128(\mathrm{~s})$ & - \\
\hline 604-Dec-26 & $\mathrm{P}$ & $13: 31: 58$ & 42 & - & 15:07:32 & 30 & 224 & - & 16:29:02 & 16 & 0.83 & 0.78 & - \\
\hline 606-Jun-11 & $\mathrm{P}$ & $09: 11: 35$ & 47 & - & 10:39:27 & 67 & 080 & - & 12:25:10 & 87 & 0.473 & 0.356 & - \\
\hline 612-Aug-02 & $\mathrm{P}$ & 18:37:12 & 03 & - & $18: 53(s)$ & $0(s)$ & 289 & - & 18:53(s) & $0(s)$ & $0.328(\mathrm{~s})$ & $0.217(\mathrm{~s})$ & - \\
\hline 613-Jul-23 & $\mathrm{P}$ & 07:03:06 & 16 & - & 08:12:20 & 31 & 079 & - & 09:32:11 & 50 & 0.934 & 0.923 & - \\
\hline 616-May-21 & $P$ & $07: 12: 05$ & 20 & - & $08: 25: 01$ & 37 & 080 & - & $09: 51: 43$ & 57 & 0.802 & 0.743 & - \\
\hline 617-Nov-04 & $\mathrm{P}$ & $08: 47: 41$ & 28 & - & 10:19:46 & 44 & 143 & - & 12:06:37 & 52 & 0.609 & 0.503 & - \\
\hline 620-Sep-02 & $\mathrm{P}$ & $07: 06: 08$ & $\overline{14}$ & - & $08: 10: 18$ & 29 & 094 & - & 09:22:57 & 45 & 0.77 & 0.718 & - \\
\hline
\end{tabular}

Sumber: NASA (https://eclipse.qsfc.nasa.gov/JSEX/JSEX-AS.html)

2. Data gerhana matahari periode Madinah (622-632 M)

Tahun 624 : 21 Juni $624 \mathrm{M} / 29$ Dzulhijjah $2 \mathrm{H}$

Tahun 627 : 21 April $627 \mathrm{M} / 29$ Dzulqa'dah $5 \mathrm{H}$

Tahun 628 : 3 Oktober 628 M/ 29 Jumadil Awal 7 H

Tahun 632 : 27 Januari 632 M/ 29 Syawal $10 \mathrm{H}$

Longitude: $39^{\circ} 49^{\prime} 41^{\prime \prime} \mathrm{E}$

Altitude: $604 \mathrm{~m}$

Time Zone: 03:00 E

\begin{tabular}{|c|c|c|c|c|c|c|c|c|c|c|c|c|c|}
\hline $\begin{array}{l}\text { Calendar } \\
\text { Date }\end{array}$ & \begin{tabular}{|l|} 
Eclipse \\
Type
\end{tabular} & \begin{tabular}{|l|} 
Partial \\
Eclipse \\
Begins
\end{tabular} & \begin{tabular}{|l|} 
Sun \\
Alt
\end{tabular} & \begin{tabular}{|l} 
A or T \\
Eclipse \\
Begins
\end{tabular} & \begin{tabular}{|l} 
Maximum \\
Eclipse
\end{tabular} & $\begin{array}{l}\text { Sun } \\
\text { Alt }\end{array}$ & \begin{tabular}{|l|} 
Sun \\
Azi
\end{tabular} & \begin{tabular}{|l} 
A or T \\
Eclipse \\
Ends
\end{tabular} & \begin{tabular}{|l} 
Partial \\
Eclipse \\
Ends
\end{tabular} & $\begin{array}{l}\text { Sun } \\
\text { AIt }\end{array}$ & $\begin{array}{l}\text { Eclipse } \\
\text { Mag. }\end{array}$ & $\begin{array}{l}\text { Eclipse } \\
\text { Obs. }\end{array}$ & \begin{tabular}{|l} 
A or T \\
Eclipse \\
Duration
\end{tabular} \\
\hline 601-Mar-10 & $\mathrm{P}$ & $09: 36: 18$ & 39 & - & 10:59:00 & 54 & 138 & - & 12:28:10 & 62 & 0.816 & 0.775 & - \\
\hline 603-Aug-12 & $\mathrm{P}$ & 18:33:00 & 04 & - & 18:52(s) & $\overline{O(s)}$ & 286 & - & 18:52(s) & $\mid O(s)$ & $0.379(\mathrm{~s})$ & $0.267(\mathrm{~s})$ & - \\
\hline 604-Dec-26 & $\mathrm{P}$ & $13: 30: 28$ & 40 & - & 15:06:10 & 28 & 222 & - & 16:28:07 & 14 & 0.901 & 0.869 & - \\
\hline 606-Jun-11 & $\mathrm{P}$ & $09: 13: 44$ & 48 & - & 10:45:46 & 69 & 088 & - & 12:35:30 & $\overline{86}$ & 0.55 & 0.44 & - \\
\hline 612-Aug-02 & $\mathrm{P}$ & 18:34:11 & 05 & - & 18:58(s) & $O(s)$ & 289 & - & 18:58(s) & $O(s)$ & $0.458(\mathrm{~s})$ & $0.35(\mathrm{~s})$ & - \\
\hline 613-Jul-23 & $\mathrm{P}$ & 07:05:01 & 17 & - & 08:13:07 & 32 & 081 & - & $09: 30: 58$ & 50 & 0.836 & 0.799 & - \\
\hline 616-May-21 & $\mathrm{P}$ & $07: 15: 28$ & 22 & - & 08:29:41 & 38 & 082 & - & 09:57:41 & 58 & 0.877 & 0.835 & - \\
\hline 617-Nov-04 & $\mathrm{P}$ & $08: 44: 32$ & 26 & - & 10:17:46 & 41 & 144 & - & 12:05:59 & 49 & 0.68 & 0.585 & - \\
\hline 620-Sep-02 & $\mathrm{P}$ & $07: 08: 38$ & 14 & - & $08: 10: 35$ & 28 & 095 & - & 09:20:07 & 44 & 0.67 & 0.594 & - \\
\hline 624-Jun-21 & $\mathrm{P}$ & 18:42:48 & 05 & - & 19:07(s) & $O(s)$ & 296 & - & 19:07(s) & $O(s)$ & $0.345(\mathrm{~s})$ & $0.226(\mathrm{~s})$ & - \\
\hline 627-Apr-21 & $\mathrm{P}$ & 10:31:36 & 62 & - & 10:57:45 & 68 & 119 & - & 11:24:20 & 73 & 0.06 & 0.018 & - \\
\hline 628-Oct-03 & $\mathrm{P}$ & $06: 17(r)$ & $O(r)$ & - & $06: 27: 59$ & 02 & 097 & - & $06: 58: 07$ & 09 & 0.118 & 0.047 & - \\
\hline 632-Jan-27 & $P$ & $07: 16: 05$ & 01 & - & 08:29:30 & $\overline{16}$ & 119 & - & $09: 54: 57$ & 32 & 0.819 & 0.765 & - \\
\hline
\end{tabular}

Sumber: NASA (https://eclipse.gsfc.nasa.gov/JSEX/JSEX-AS.html)

Data astronomi menunjukkan bahwa gerhana pada tahun $10 \mathrm{H}$ (yang menurut riwayat hadis-hadis shahih menyebutkan bahwa gerhana terjadi bersamaan dengan hari wafatnya putera Nabi SAW yaitu Ibrahim) adalah gerhana matahari yang terjadi pada hari 
senin 27 januari $632 \mathrm{M}$ dan bertepatan dengan tanggal 29 Syawal $10 \mathrm{H}$. Dengan demikian riwayat-riwayat yang menyatakan bahwa peristiwa gerhana matahari pada hari kematian Ibrahim terjadi tanggal 10, 4, atau 14 bulan Rabiul Awal, Ramadhan, atau Dzulhijjah tahun $10 \mathrm{H}$ tidak dapat diterima berdasarkan analisis astronomi. Oleh karena itu, hadis atTabarani dari Sirin yang di dalamnya dinyatakan bahwa kematian Ibrahim yang bertepatan dengan gerhana matahari adalah pada hari selasa 10 Rabiul Awal $10 \mathrm{H}$ adalah daif dari segi matan karena bertentangan dengan ilmu astronomi yang tidak mungkin diingkari. Kedaifan matan hadis sebagai temuan astronomi ini sejalan dengan kedaifan sanad yang dibuktikan oleh analisis ilmu hadis sendiri. Jadi, temuan ilmu hadis sejalan dengan temuan astronomi dalam kasus hadis at-Tabarani.

Apabila kelahiran Ibrahim ditentukan berdasarkan riwayat hadis dan tarikh yaitu pada bulan Dzulhijjah $8 \mathrm{H}$ dan wafatnya ditentukan berdasarkan analisis astronomi yaitu pada 29 Syawal $10 \mathrm{H}$, maka usia Ibrahim saat meninggal adalah 1 tahun 10 bulan (22 bulan). Dengan demikian riwayat-riwayat yang menyebutkan bahwa usia Ibrahim saat meninggal adalah 70 malam, 16 bulan atau 18 bulan tidak sesuai dengan hasil temuan astronomi. Oleh karena itu, hadis riwayat 'Abd ar-Razzaq yang menyatakan usia Ibrahim saat meninggal 16 bulan adalah tidak benar. Dengan demikian, meskipun dalam hadis tersebut sanadnya sahih namun karena matannya tidak sahih, maka hadis tersebut menjadi daif. Jadi, dalam kasus ini analisis astronomi dapat mendaifkan suatu hadis yang sahih sanadnya. Pada sisi lain riwayat-riwayat yang menyebutkan bahwa usia Ibrahim saat meninggal adalah 1 tahun 10 bulan sejalan dengan temuan analisis astronomi. ${ }^{21}$

\section{SIMPULAN}

Dari hadis-hadis diatas, dapat disimpulkan bahwa fenomena gerhana terjadi bukan karena kematian atau kehidupan seseorang, melainkan sebagai bukti kekuasaan Allah yang maha kuasa. SehIngga sebagai muslim disunahkan untuk melaksanakan Salat gerhana ketika terjadi fenomena gerhana, yaitu baik gerhana matahari maupun gerhana bulan. Gerhana mathari disebut dengan istilah kusuf asy-syams, sedangkan gerhana bulan disebut khusuf al-qamar.

\footnotetext{
${ }^{21}$ Syamsul Anwar, Interkoneksi, .......... hlm. 176-177.
} 
Dengan merujuk pada riwayat-riwayat hadis yang mayoritas menyebut bahwa Ibrahim meninggal pada tahun $10 \mathrm{H}$ dan mencocokkannya dengan data astronomi terkait waktu terjadinya gerhana matahari pada zaman Nabi SAW, maka dapat disimpulkan bahwa Ibrahim Ibn Muhammad SAW meninggal pada hari senin 27 Januari $632 \mathrm{M}$ atau bertepatan dengan 29 Syawal $10 \mathrm{H}$, sehingga jika dihitung usia Ibrahim adalah 1 tahun 10 bulan (22 bulan).

\section{DAFTAR PUSTAKA}

Ad-Darimi, I. (2007). Sunan Ad-Darimi. terj. Abdul Syukur Abdul Razaq, Jakarta: Pustaka Azzam, jilid I.

Al-Mundziry, H. (1992). Mukhtashar Sunan Abi Dawud. terj. Bey Arifin dan A. Syinqithy Djamaluddin, Semarang: Asy-Syifa'.

Al-Asqalani, I.H. (2008). Fathul Baari syarah: Shahih Bukhari, terj. Gazirah Abdi Ummah Jakarta: Pustaka Azzam, cet. 2, vol. VI.

An-Nawawi, I. (2014). Syarah Shahih Muslim, terj. Team Darus Sunnah, Jakarta: Darus Sunnah, cet. 3, vol. 4.

Anwar, S. (2011). Interkoneksi Studi Hadis dan Astronomi, Yogyakarta: Suara Muhammadiyah.

Ar-Razzaq, A. (1403). al-Mushannaf. edisi Habib ar-Rahman. Beirut: al-Maktab al-Islami.

At-Tabarani. (1983). al-Mu’jam al-Kabir. edisi Hamdi Ibn 'Abd al-Majid asSilafi, cet. Ke-2, Mosul, Suriah: Maktabat az-Zahra, XXIV.

Khazin, M. (2004). Ilmu Falak dalam Teori dan praktik, Yogyakarta: Buana Pustaka, cet. 3.

\section{Jurnal/Artikel}

Hamdani, F.F.R.S. (2016). Penerapan Model Contextual Teaching and Learning (CTL) dalam Pembelajaran Ilmu Falak, Jurnal al-Murabbi, Volume. 3 (1). 56.

https://eclipse.gsfc.nasa.gov/JSEX/JSEX-AS.html, diakses pada 8 Desember 2017 pukul 04.50 WIB. 